\title{
Effective systemic treatment of advanced periocular basal cell carcinoma with sonidegib
}

\author{
Alexander C. Rokohl ${ }^{1,2} \cdot$ Ludwig M. Heindl ${ }^{1,2}$ D
}

Received: 23 June 2021 / Revised: 23 June 2021 / Accepted: 2 July 2021 / Published online: 2 August 2021

(c) The Author(s) 2021

\section{Dear Editor,}

With great interest, we read the "Letter to the Editor" of our highly appreciated colleague Nilay Yuksel. Indeed, targeted therapy for periocular and orbital tumors is becoming an exploding and hot topic for ophthalmologists and oncologists [1-5]. Sonidegib (Odomzo®) is an oral hedgehog pathway inhibitor (HPI) and that it is indicated for the treatment of adults with locally advanced basal cell carcinomas (BCCs) [2, 6, 7].

Locally advanced BCCs are defined as a subgroup of tumors that require an interdisciplinary therapeutic concept, especially in the case of an orbital involvement [5, 8]. After obtaining specific surgical and interdisciplinary expertise (tumor board), in some cases, alternative approaches to surgical excision are required since an $\mathrm{R} 0$ resection cannot be reliably achieved due to advanced stage of the tumor, cosmetic changes after surgery, or multiple BCC lesions [5, $9,10]$. Our patient refused any surgical or radiotherapeutic interventions due to the expected multiple surgeries as well as cosmetic disfigurements and preferred systemic treatment [2]. In addition, a reason for the patient for preferring systemic therapy was the long-term history with multiple recurrent BCCs in other locations [2]. Therefore, oral treatment with sonidegib (capsule $200 \mathrm{mg}$; Odomzo®) once a day for 6 months was administered for the treatment of the periocular BCC and for preventing potential further recurrent BCCs. Since the spread of the morphea BCC included the full width of the lower eyelid, a simple resection with ectropion surgery seemed not to be feasible [2, 9]. Rather,

Ludwig M. Heindl

ludwig.heindl@uk-koeln.de

1 Department of Ophthalmology, Faculty of Medicine and University Hospital Cologne, University of Cologne, Kerpener Strasse 62, 50937 Cologne, Germany

2 Center for Integrated Oncology (CIO) Aachen-Bonn-Colog ne-Düsseldorf, Cologne, Germany an extensive excision with a complex reconstruction (for example Hughes procedure) would have been necessary to achieve $\mathrm{R} 0$ resection with a good cosmetic result [9].

Our patient was treated successfully with sonidegib and had only slight and rarely occurring side effects not reducing significantly the quality of life [2]. However, the authors also usually recommend a surgical approach and consider the advantages of the surgery over these costly drugs, especially since the long-term efficacy and complications are not fully investigated $[2,9]$. In summary with the patient's therapy wishes and his medical history with multiple BCCs, personalized systemic therapy with the oral hedgehog pathway inhibitor (HPI) sonidegib (Odomzo®) was a good option in this case with very high patient satisfaction. Nevertheless, due to possible serious side effects, the indication for systemic treatment must always be very narrow.

Funding Open Access funding enabled and organized by Projekt DEAL.

\section{Declarations}

Ethics approval All procedures performed in studies involving human participants were in accordance with the ethical standards of the institutional research committee and with the 1964 Helsinki Declaration and its later amendments or comparable ethical standards.

Conflict of interest The authors declare no competing interests.

Open Access This article is licensed under a Creative Commons Attribution 4.0 International License, which permits use, sharing, adaptation, distribution and reproduction in any medium or format, as long as you give appropriate credit to the original author(s) and the source, provide a link to the Creative Commons licence, and indicate if changes were made. The images or other third party material in this article are included in the article's Creative Commons licence, unless indicated otherwise in a credit line to the material. If material is not included in the article's Creative Commons licence and your intended use is not permitted by statutory regulation or exceeds the permitted use, you will 
need to obtain permission directly from the copyright holder. To view a copy of this licence, visit http://creativecommons.org/licenses/by/4.0/.

\section{References}

1. Rokohl AC, Koch KR, Mor JM, Loreck N, Schlaak M, Mauch C, Bechrakis NE, Mohi A, Kakkassery V, Heindl LM (2020) Personalized medicine in the treatment of periocular tumors: targeted treatment and use of immune checkpoint inhibitors. Ophthalmologe 117:521-527. https://doi.org/10.1007/s00347-019-01034-z

2. Hou X, Rokohl AC, Ortmann M, Heindl LM (2020) Effective treatment of locally advanced periocular basal cell carcinoma with oral hedgehog pathway inhibitor? Graefes Arch Clin Exp Ophthalmol 258:2335-2337. https://doi.org/10.1007/s00417-020-04779-5

3. Kakkassery V, Emmert S, Adamietz IA, Kovacs G, Junemann AM, Otte C, Zimbelmann M, Brosig A, Grisanti S, Heindl LM (2020) Alternative treatment options for periorbital basal cell carcinoma. Ophthalmologe 117:113-123. https://doi.org/10.1007/ s00347-019-01021-4

4. Lauterbach B, Kakkassery V, Debus D, Heindl LM, Schultz ES (2019) Advanced periocular basal cell carcinoma-a therapeutic challenge. Ophthalmologe 116:273-277. https://doi.org/10.1007/ s00347-018-0734-9

5. Lang BM, Balermpas P, Bauer A, Blum A, Brolsch GF, Dirschka T, Follmann M, Frank J, Frerich B, Fritz K, Hauschild A, Heindl LM, Howaldt HP, Ihrler S, Kakkassery V, Klumpp B, KrauseBergmann A, Loser C, Meissner M, Sachse MM, Schlaak M, Schon MP, Tischendorf L, Tronnier M, Vordermark D, Welzel J, Weichenthal M, Wiegand S, Kaufmann R, Grabbe S (2019) S2k guidelines for cutaneous basal cell carcinoma - part 2: treatment, prevention and follow-up. J Dtsch Dermatol Ges 17:214-230. https://doi.org/10.1111/ddg.13755

6. Mathis J, Doerr T, Lin E, Ibrahim SF (2019) Oral hedgehog pathway inhibition as a means for ocular salvage in locally advanced intraorbital basal cell carcinoma. Dermatol Surg 45:17-25. https:// doi.org/10.1097/DSS.0000000000001640

7. Kakkassery V, Loeffler KU, Sand M, Koch KR, Lentzsch AM, Nick AC, Adamietz IA, Heindl LM (2017) Current diagnostics and therapy recommendations for ocular basal cell carcinoma. Ophthalmologe 114:224-236. https://doi.org/10.1007/ s00347-016-0370-1

8. Rokohl AC, Koch KR, Kabbasch C, Kreppel M, Luers JC, Grau S, Heindl LM (2019) Importance of interdisciplinary collaboration for optimal treatment of orbital tumors. HNO 67:528-533. https:// doi.org/10.1007/s00106-019-0659-x

9. Rokohl AC, Kopecky A, Guo Y, Kakkassery V, Mor JM, Loreck N, Koch KR, Heindl LM (2020) Surgical resection with ophthalmoplastic reconstruction: gold standard in periocular basal cell carcinoma. Ophthalmologe 117:95-105. https://doi.org/10.1007/ s00347-019-00973-x

10. Rokohl AC, Loser H, Mor JM, Loreck N, Koch KR, Heindl LM (2020) Young male patient with unusual space-occupying lesion of the lower eyelid. Ophthalmologe 117:73-77. https://doi.org/10. 1007/s00347-019-00948-y

Publisher's note Springer Nature remains neutral with regard to jurisdictional claims in published maps and institutional affiliations. 